\title{
UPAYA MENINGKATKAN MINAT BELAJAR SISWA DALAM \\ PEMBELAJARAN PKN MELALUI PENDEKATAN \\ PEMBELAJARAN DI LUAR KELAS
}

\author{
Dewi Setyorini \\ SMAN 1 Kelapa \\ dewisrijuanda@gmail.com
}

\begin{abstract}
Abstrak
Penelitian ini dilatarbelakangi oleh adanya permasalahan terkait dengan rendahnya minat belajar dan pemahaman konsep XII PKn 1 SMAN 1 Kelapa. Penelitian ini bertujuan untuk meningkatkan minat belajar siswa di dalam pembelajaran Pendidikan Kewarganegaraan (PKn) menggunakan pendekatan pembelajaran di luar kelas. Jenis penelitian ini yaitu Tindakan Kelas (Classroom Action Research). Teknik pengumpulan data menggunakan observasi, angket, tes, dan dokumentasi. Teknik analisis data menggunakan analisis kualitatif dan kuantitatif. Subjek penelitian yaitu siswa kelas XII IPA 1 SMAN 1 Kelapa semester I Tahun Pelajaran 2018/2019. Data hasil penelitian tindakan kelas yang dilaksanakan dapat diketahui bahwa minat belajar siswa di dalam pembelajaran PKN terjadi peningkatan di setiap siklus. Siswa lebih antusias di dalam mengikuti pembelajaran di luar kelas dibandingkan dengan proses pembelajaran yang dilakukan di dalam kelas. Peningkatan minat ini dapat diketahui melalui hasil observasi dan wawancara yang dilakukan, serta dipertegas dengan meningkatnya hasil belajar siswa. Hasil belajar siswa ini dapat dilihat dari nilai rata - rata persentase hasil tes siswa pada siklus I sebesar $42,22 \%$ menjadi 85,55\%. Rata - rata nilai PKN siswa meningkat dari siklus I sebesar 75,92 menjadi 90,74 pada siklus II.
\end{abstract}

Kata Kunci: Minat Belajar; Pembelajaran di Luar Kelas; Hasil Belajar.

\begin{abstract}
Research This research is motivated by problems related to the lack of interest in learning and understanding the concept of XII PKn 1 SMAN 1 Kelapa. This study aims to increase student interest in learning Citizenship Education (Civics) using a learning approach outside the classroom. This type of research is Classroom Action Research. Data collection techniques using observation, questionnaires, tests and documentation. Data analysis techniques using qualitative and quantitative analysis. The research subjects are students of class XII IPA 1 of SMAN 1 Kelapa in the first semester of 2018/2019 Academic Year. Data on the results of classroom action research conducted can be seen that student interest in learning in PKN has increased in each cycle. Students are more enthusiastic in participating in learning outside the classroom compared to the learning process carried out in the classroom. This increased interest can be seen through the results of observations and interviews conducted, and is confirmed by the increase in student learning outcomes. Student learning outcomes can be seen from the average value of the percentage of student test results in the first cycle of $42.22 \%$ to $85.55 \%$. The average PKN score of students increased from cycle I by 75.92 to 90.74 in cycle II.
\end{abstract}


Edutainment : Jurnal Ilmu Pendidikan dan Kependidikan

Volume 8 Nomor 1 Edisi Januari - Juni 2020

Keywords: Interest in Learning; Learning Outside the Class; Learning Outcome.

\section{PENDAHULUAN}

Menurut Undang - Undang Nomor

20 Tahun 2003, Sistem Pendidikan

Nasional didefinisikan sebagai usaha sadar dan terencana untuk mewujudkan suasana belajar dan proses belajar agar peserta didik secara aktif mengembangkan potensi didik dirinya untuk memiliki kekuatan spiritual secara keagamaan, pengendalian diri, kecerdasan, akhlak mulia, serta keterampilan yang diperlukan dirinya, masyarakat, bangsa, dan negara.

Pendidikan formal banyak ditentukan oleh keberhasilan dari proses pembelajaran, yakni keterpaduan antara kegiatan guru dan kegiatan siswa. Dalam rangka meningkatkan kualitas serta kuantitas kegiatan belajar mengajar banyak upaya yang seharusnya dilakukan oleh guru, sehingga terjadi interaksi yang seimbang antara guru dengan siswa dalam interaksi belajar mengajar.

Pendidikan Kewarganegaraan (merupakan salah satu mata pelajaran wajib setiap jenjang persekolahan dan materinya perlu dipahami dengan baik, namun kenyataannya masih ada siswa yang kurang senang dan bahkan tidak berminat di dalam proses pembelajaran
PKn. Bagi kebanyakan siswa pelajaran ini sangat membosankan.

Pembelajaran PKn yang dilaksanakan sekolah pada umumnya cenderung masih mengikuti pembelajaran konvensional yang monoton dengan menggunakan pembelajaran di dalam kelas saja. Hal ini menyebabkan minat belajar siswa dalam mengikuti proses pembelajaran masih rendah, sehingga menyebabkan minat belajar PKn siswa rendah pula.

Minat siswa terhadap mata pelajaran PKn akan sangat berpengaruh terhadap keberhasilan pembelajaran pada mata pelajaran tersebut. Menurut Slameto (2010:180) minat adalah rasa lebih suka dan rasa keterikatan pada suatu hal atau aktivitas, tanpa ada yang menyuruh. Minat pada dasarnya merupakan penerimaan suatu hubungan antara diri sendiri dengan sesuatu di luar diri, semakin kuat atau dekat hubungan tersebut, semakin besar minatnya.

Menurut Djaali (2007), "minat adalah rasa lebih suka dan rasa keterikatan pada sesuatu hal atau aktivitas tanpa ada yang menyuruh". Hal senada diungkapkan pula oleh Slameto (2010) bahwa "minat sebagai kecenderungan yang tetap untuk memperhatikan terus-menerus yang 
Edutainment : Jurnal Ilmu Pendidikan dan Kependidikan

Volume 8 Nomor 1 Edisi Januari - Juni 2020

disertai rasa senang". Dari pernyataan tersebut mengindikasikan bahwa minat dicirikan dengan rasa lebih suka, rasa tertarik atau rasa senang sebagai bentuk ekspresi terhadap sesuatu hal yang diminati.

\section{Menurut Slameto}

(2010:180) beberapa indikator minat belajar, yakni perasaan senang, ketertarikan, penerimaan, dan keterlibatan siswa. Berdasarkan beberapa definisi yang dikemukakan mengenai indikator minat belajar tersebut di atas, indikator minat sebagai berikut:

Pertama, perasaan senang, yakni apabila seorang siswa memiliki perasaan senang terhadap pelajaran tertentu, maka tidak akan ada rasa terpaksa untuk belajar. Contohnya senang mengikuti pelajaran, tidak ada perasaan bosan, dan hadir saat pelajaran. Kedua, keterlibatan siswa, yakni ketertarikan seseorang akan objek yang mengakibatkan orang tersebut senang dan tertarik untuk melakukan atau mengerjakan kegiatan dari objek tersebut. Contohnya aktif dalam diskusi, aktif bertanya, dan aktif menjawab pertanyaan dari guru.

Ketiga, ketertarikan, yakni berhubungan dengan daya dorong siswa terhadap ketertarikan pada sesuatu benda, orang, kegiatan atau bias berupa pengalaman afektif yang dirangsang oleh kegiatan itu sendiri. Contohnya antusias dalam mengikuti pelajaran, tidak menunda tugas dari guru. Keempat, perhatian siswa, yakni minat dan perhatian merupakan dua hal yang dianggap sama dalam penggunaan sehari-hari, perhatian siswa merupakan konsentrasi siswa terhadap pengamatan dan pengertian, dengan mengesampingkan yang lain. Siswa memiliki minat pada objek tertentu, maka dengan sendirinya akan memperhatikan objek tersebut. Contohnya mendengarkan penjelasan guru dan mencatat materi.

Benyamin S. Bloom mengatakan bahwa lingkungan sebagai kondisi, daya, dan dorongan eksternal dapat memberikan suatu situasi "Kerja" di sekitar murid. Karena itu lingkungan secara keseluruhan dapat berfungsi sebagai daya untuk membentuk dan memberi kekuatan/dorongan eksternal untuk belajar anak (Nurdin, 2005). Minat siswa terhadap mata pelajaran PKn yang rendah tentu akan berpengaruh terhadap keberhasilan pembelajaran.

Permasalahan ini memerlukan solusi yang tepat diperlukan suatu jalan keluar yang tepat agar pembelajaran berjalan sesuai dengan tujuan. Alternatif pemecahannya dengan menggunakan variasi metode pembelajaran, metode yang bervariasi dapat meningkatkan minat belajar dan pemahaman konsep 
Edutainment : Jurnal Ilmu Pendidikan dan Kependidikan

Volume 8 Nomor 1 Edisi Januari - Juni 2020

siswa. Menerapkan metode pembelajaran di luar kelas (outdoor study) merupakan alternatif pilihan dalam penelitian ini. Pada pembelajaran ini siswa akan dihadapkan pada realita, siswa tidak hanya belajar dengan menerima apa yang diberikan guru saja, melainkan juga dapat melakukan aktivitas belajar seperti pengamatan, diskusi, dan observasi langsung di lapangan.

Husamah (2013:23) menyatakan metode (outdoor study) merupakan metode dimana guru mengajak siswa belajar di luar kelas untuk melihat peristiwa langsung di lapangan dengan tujuan untuk mengakrabkan siswa dengan lingkungannya. Lingkungan menyediakan sumber ilmu yang bersifat konkret yang dibutuhkan oleh siswa. Selain itu, kegiatan belajar akan lebih aktif, kreatif, variatif dengan memanfaatkan lingkungan sekitar.

Metode outdoor study dipilih karena pada hakikatnya belajar merupakan interaksi antara individu dengan lingkungannya. Siswa secara aktif dapat terlibat dalam proses pembelajaran, sehingga pembelajaran PKn menarik bagi siswa untuk dipelajari. Metode outdoor study merupakan pembelajaran yang menyenangkan, menantang dan menggembirakan (Farida, dkk., 2012:241). Diperlukan pembelajaran dengan metode outdoor study agar pembelajaran lebih aktif, kreatif, variatif, dan akrab dengan lingkungannya. Pembelajaran dengan metode outdoor study dapat disajikan secara konkret, bahan yang dipelajari lebih banyak, dan langsung sehingga kebenarannya akurat.

\section{METODOLOGI PENELITIAN}

Pada penelitian ini metode yang digunakan metode tindakan kelas (classroom action research). Metode pada dasarnya berarti cara yang dipergunakan untuk mencapai tujuan. Metode penelitian merupakan langkah dan cara dalam mencari, merumuskan, menggali data, menganalisis, membahas dan menyimpulkan masalah dalam penelitian (Musfiqon, 2015:14).

Subjek penelitian ini siswa kelas XII IPA 1 SMA N 1 Kelapa semester I Tahun Pelajaran 2018/2019. Data yang diperoleh dari penelitian ini adalah hasil pengamatan oleh observer, hasil wawancara, dan hasil tes tertulis siswa kelas XII IPA I SMA N 1 Kelapa pada siklus I dan penilaian siklus II.

\section{HASIL DAN PEMBAHASAN}

\section{Hasil Penelitian}

Selama kegiatan berlangsung diadakan observasi secara langsung terhadap minat siswa dalam pembelajaran PKN. Minat belajar siswa 
Edutainment : Jurnal Ilmu Pendidikan dan Kependidikan

Volume 8 Nomor 1 Edisi Januari - Juni 2020

pada pertemuan I sudah ada kemajuan dibanding dengan minat belajar siswa pada saat pra tindakan. Siswa sudah mulai tertarik dengan pembelajaran PKN, siswa senang mengikuti pembelajaran ditunjukkan dengan ekspresi riang gembira. Siswa sudah mulai mempunyai keinginan untuk belajar. Siswa sudah memperhatikan dalam mengikuti pembelajaran dengan cukup baik. 34 Siswa sudah memperhatikan penjelasan dari guru, siswa mengerjakan tugas yang diberikan guru, siswa sudah tertarik dalam mengikuti pembelajaran PKn. Masalah yang dihadapi yaitu siswa ramai dan mengobrol dengan teman-temannya pada saat berdiskusi, serta berjalan kesana-kemari.

Pembelajaran dengan metode outdoor study siklus I dilaksanakan dengan menggunakan tahap pra tindakan, pengembangan, penerapan, dan penutup. Keterlaksanaan metode outdoor study siklus I dalam pembelajaran.

Selama kegiatan outdoor study berlangsung diadakan observasi secara langsung terhadap minat siswa dalam pembelajaran PKn. Minat belajar siswa pada pertemuan I sudah ada kemajuan dibandingkan dengan minat belajar siswa pada saat pra tindakan. Siswa sudah mulai tertarik dengan pembelajaran PKn, siswa senang mengikuti pembelajaran ditunjukkan dengan ekspresi riang gembira. Siswa sudah mulai mempunyai keinginan untuk belajar. Siswa sudah memperhatikan dalam mengikuti pembelajaran dengan cukup baik.

Persentase hasil penelitian tindakan kelas yang dilakukan sebanyak dua siklus dapat disajikan sebagai berikut : 1) Aktivitas Siswa Selama Mengikuti Pembelajaran, Aktivitas siswa selama mengikuti pembelajaran meningkat dari tiap siklus. Hal ini didapat dari hasil pengamatan atau observasi yang dilakukan peneliti. Hasil tersebut disajikan dalam diagram sebagai berikut:

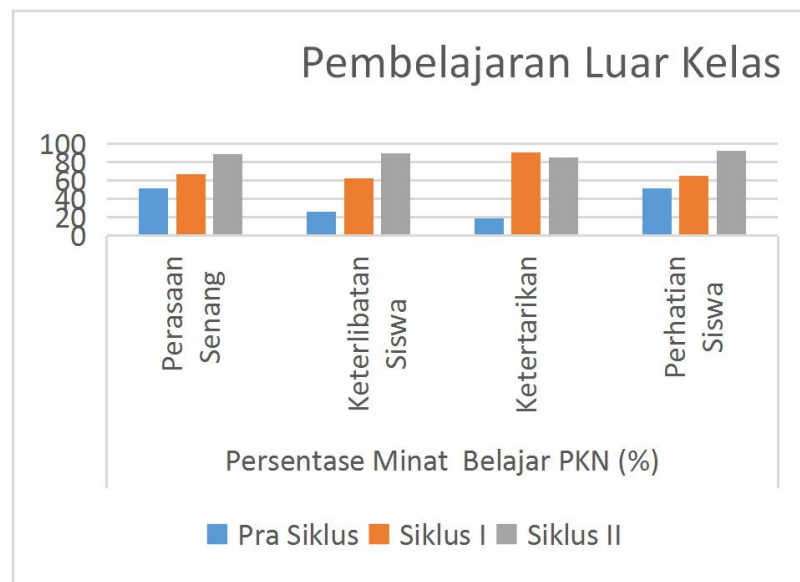

Grafik 1. Hasil Observasi Minat Belajar

Berdasarkan persentase hasil dalam diagram di atas dapat diketahui bahwa proses pembelajaran dengan metode outdoor study pada siklus I sudah terlaksana dengan baik dengan persentase $66,67 \%$ siswa merasa senang belajar PKn, ini menunjukkan bahwa terjadi peningkatan sebanyak 14,81\% siswa yang merasa senang pembelajaran 
Edutainment : Jurnal Ilmu Pendidikan dan Kependidikan

Volume 8 Nomor 1 Edisi Januari - Juni 2020

PKn. Siswa juga mulai terlibat aktif di dalam proses pembelajaran outdoor study pada siklus 1. Hal ini dapat dilihat persentase hasil dai sebelum diberikan tindakan terjadi peningkatan sebanyak $36,8 \%$. Begitupun dengan ketertarikan dan perhatian siswa di dalam mengikuti pembelajaran PKn dengan menggunakan metode outdoor study.

Peningkatan aktivitas tersebut juga dapat dilihat dari aktivitas siswa dalam mengikuti pelajaran, keaktifan siswa dalam mengajukan dan menjawab pertanyaan, rasa ingin tahu dan keberanian siswa meningkat, kreatifitas dan inisiatif siswa meningkat, serta aktif dalam menyelesaikan soal yang diberikan. Perkembangan hasil tes kemampuan siswa dalam pembelajaran dapat disajikan dalam diagram perolehan nilai rata - rata kelas sebagai berikut:

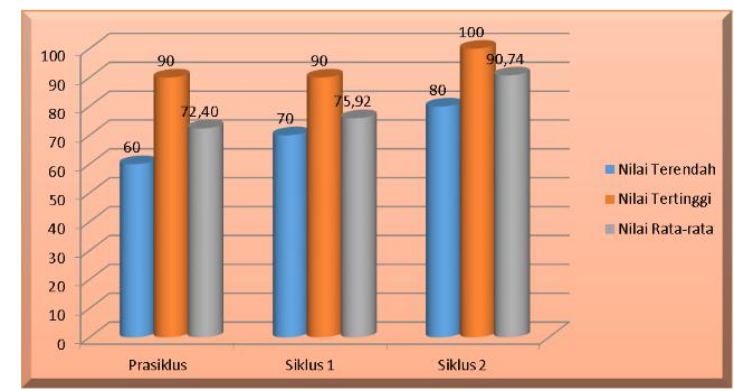

Grafik 2. Perolehan Nilai Per - Siklus

Dari hasil penelitian tindakan kelas tentang upaya meningkatkan hasil belajar siswa kelas XII IPA 2 SMA Negeri 1 Kelapa dengan menggunakan metode belajar yang bervariasi tahun pelajaran 2018/2019 yang dilakukan dapat dilihat bahwa terjadi peningkatan nilai rata - rata di setiap siklus. Hal ini disebabkan karena pada saat perbaikan metode pembelajaran yang diterapkan berbeda dari sebelumnya. Penggunaan metode konvensional atau ceramah diganti dengan metode pembelajaran di luar kelas/tempat belajar yang bervariasi lebih mudah diterima oleh siswa.

\section{Pembahasan Penelitian}

Penelitian berupa pengamatan tindakan dan rekapitulasi kuesioner siswa pada siklus I dan II dapat dianalisis sebagai berikut: 1) Kurangnya keterlibatan siswa di dalam proses pembelajaran, c) Kurangnya ketertarikan, bertanya dan menyimpulkan. Hasil kuesioner siswa pada siklus I menunjukkan bahwa sebagian siswa masih kurang minat dalam belajar dan memahami materi PKn, bekerja sama, membuat kesimpulan, dan belum mengikuti pembelajaran yang penuh perhatian dari awal sampai akhir. Hasil pengamatan dan kuesioner siswa pada siklus I menunjukkan minat siswa terhadap pembelajaran Pendidikan Pancasila Kewarganegaraan (PKn) yang dilakukan di Serambi Mushola cukup tinggi. 2) Adanya peningkatan di segala aspek. Persentase hasil kuesioner juga menunjukkan adanya peningkatan dalam segala aspek, hanya sebagian kecil siswa 
Edutainment : Jurnal Ilmu Pendidikan dan Kependidikan

Volume 8 Nomor 1 Edisi Januari - Juni 2020

yang mengalami kesulitan dalam bekerja sama. Hasil pengamatan dan kuesioner siswa pada siklus II menunjukkan minat siswa terhadap pembelajaran Pendidikan Pancasila dan Kewarganegaraan (PPKn) yang dilakukan di Perpustakaan sekolah sangat tinggi.

Dari hasil keseluruhan siklus tindakan, didapatkan hasil yang sangat memuaskan yang berkenaan dengan meningkatnya minat siswa terhadap mata pelajaran PKn pada tempat pembelajaran yang bervariasi, yakni di Serambi Mushola sekolah dan Perpustakaan sekolah. 3) Peningkatan Minat Belajar, Pengujian variasi tempat belajar selain meningkatkan minat belajar sekaligus juga meningkatkan prestasi belajar siswa.

Dari hasil penelitian diperoleh data hasil belajar tiap siklus dan diperoleh data bahwa ada peningkatan kemampuan siswa. Berikut ini persentase peningkatan ketuntasan hasil belajar siswa yang mencapai KKM sebagai berikut:

Tabel 1. Persentase Ketuntasan Siswa

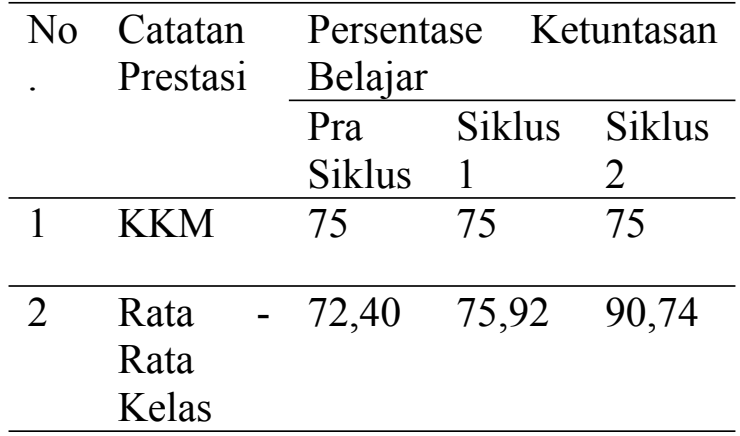

\begin{tabular}{lllll}
\hline 3 & Persenta & 36,48 & 42,22 & 85,55 \\
& se KKM & $\%$ & $\%$ & $\%$ \\
& $\geq$ KKM & & & \\
\hline 4 & Persenta & 35,92 & 33,70 & 51,85 \\
& se < & $\%$ & $\%$ & $\%$ \\
& KKM & & & \\
\hline
\end{tabular}

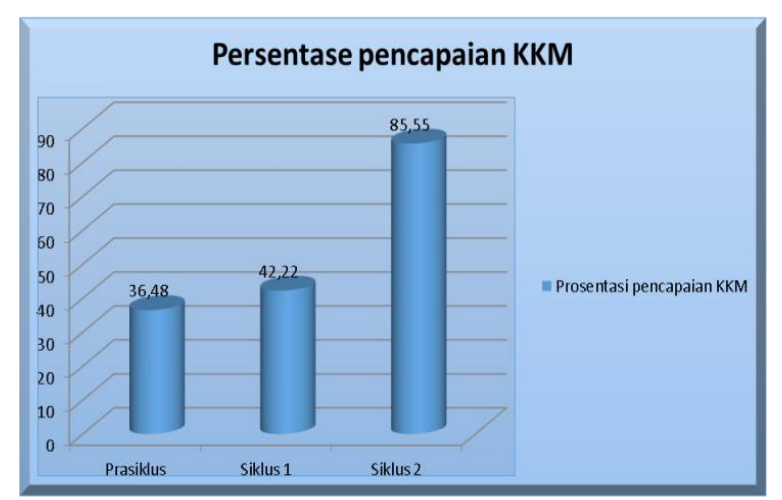

Grafik 3. Persentase Ketuntasan siswa Siswa Per Siklus

Dari tabel 1 dan grafik 3 di atas diketahui bahwa persentase ketuntasan semakin meningkat, hal ini berbanding lurus dengan jumlah siswa tuntas, sedangkan jumlah siswa yang belum tuntas semakin berkurang sejalan dengan perlakuan perbaikan pembelajaran. Pada siklus I persentase ketuntasan siswa sebesar 42,22\%. Hal ini jauh lebih baik dari pada kondisi pra siklus sebelum dilakukan tindakan perbaikan dengan persentase ketuntasan sebesar 36,48\%.

Pada siklus II jumlah siswa yang tuntas meningkat menjadi $85,55 \%$. Hal ini menandakan bahwa upaya yang dilakukan untuk memperbaiki proses pembelajaran menggunakan pembelajaran di luar kelas dapat meningkatkan hasil belajar siswa. Proses 
Edutainment : Jurnal Ilmu Pendidikan dan Kependidikan

Volume 8 Nomor 1 Edisi Januari - Juni 2020

pembelajaran yang yang digunakan dipahami oleh siswa dengan baik.

Dari hasil observasi pada tiap siklus menunjukkan keaktifan siswa mengalami peningkatan pada proses perbaikan pembelajaran. Berikut ini grafik peningkatan keaktifan belajar siswa sebagai berikut:

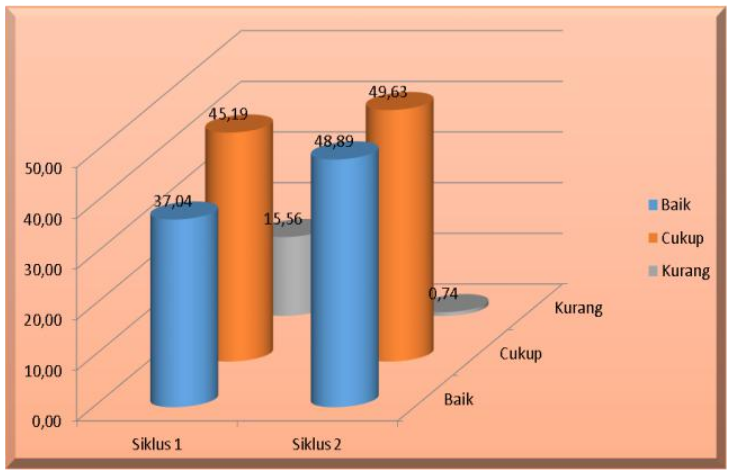

Grafik 4. Data Persentase Keaktifan

Siswa dalam Proses Pembelajaran

Dari data keaktifan siswa selama proses pembelajaran, diperoleh kesimpulan ada peningkatan keaktifan siswa dalam pembelajaran maupun minat siswa di dalam proses pembelajaran PKn.. Hal ini dapat dilihat dari meningkatnya persentase kriteria baik dan amat baik dari tiap siklus perbaikan pembelajaran. Sedangkan persentase kriteria yang kurang dan cukup terjadi penurunan.

Hasil penelitian tindakan kelas yang dilakukan sebanyak dua siklus dapat disajikan sebagai berikut: Pertama, Aktivitas Siswa Selama Mengikuti Pembelajaran, yakni aktivitas siswa selama mengikuti pembelajaran meningkat dari tiap siklus. Hal ini didapat dari hasil pengamatan atau observasi yang dilakukan peneliti. Peningkatan aktivitas tersebut dapat dilihat dari aktivitas siswa dalam mengikuti pelajaran, keaktifan siswa dalam mengajukan dan menjawab pertanyaan, rasa ingin tahu dan keberanian siswa meningkat, kreatifitas dan inisiatif siswa meningkat, serta aktif dalam menyelesaikan soal yang diberikan.

Kedua, Kemampuan Menyelesaikan Soal Menggunakan Metode pembelajaran di Luar Kelas, yakni perkembangan hasil tes kemampuan siswa dalam pembelajaran dapat disajikan dalam tabel dan grafik perolehan nilai rata-rata kelas.

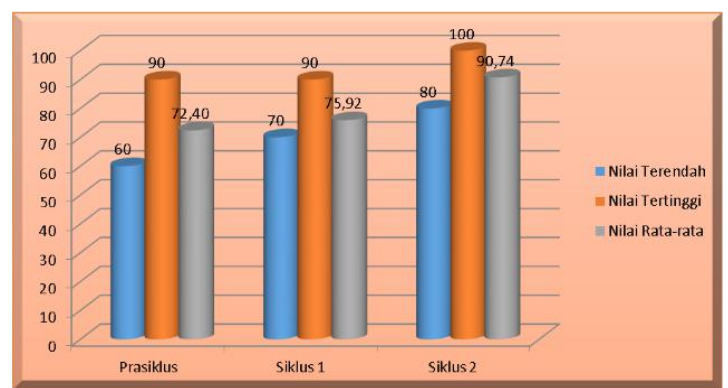

Grafik.5. Perolehan Nilai Per-Siklus

Dari hasil penelitian tindakan kelas tentang upaya meningkatkan hasil belajar siswa kelas XII IPA 2 SMA Negeri 1 Kelapa dengan menggunakan metode belajar yang bervariasi tahun pelajaran 2018/2019 yang dilakukan dapat dilihat bahwa terjadi peningkatan 
Edutainment : Jurnal Ilmu Pendidikan dan Kependidikan

Volume 8 Nomor 1 Edisi Januari - Juni 2020

nilai rata-rata di setiap siklus. Hal ini disebabkan karena pada saat perbaikan metode pembelajaran yang diterapkan berbeda dari sebelumnya. Penggunaan metode konvensional atau ceramah diganti dengan metode pembelajaran di luar kelas/tempat belajar yang bervariasi lebih mudah diterima oleh siswa.

\section{SIMPULAN DAN SARAN}

\section{Simpulan}

Berdasarkan hasil pengamatan dan observasi yang dilakukan oleh guru terhadap siswa pada penelitian tindakan kelas ini, maka dapat disimpulkan: Pertama, dengan menggunakan variasi tempat belajar dapat meningkatkan minat siswa pada Mata Pelajaran PKn kelas XII Kompetensi Dasar Menganalisis Sistem Pelaksanaan Pemerintah Negara Indonesia SMA N 1 Kelapa Tahun Pelajaran 2018/2019.

Kedua, dengan menggunakan variasi tempat belajar dapat meningkatkan prestasi belajar siswa pada Mata Pelajaran Pendiidkan Pancasila dan Kewarganegaraan (PPKn) kelas XII Kompetensi Dasar Menganalisis Sistem Pelaksanaan Pemerintahan Negara Indonesia Transparan SMA N 1 Kelapa Tahun Pelajaran 2018/2019.

\section{Saran}

Berdasarkan pada kesimpulan di atas, maka penulis menyarankan: Pertama, hendaknya penelitian tindakan kelas (classroom action research) ini, ditindaklanjuti dalam rangka meningkatkan mutu pembelajaran terutama pada mata pelajaran PKn. Kedua, hendaknya para guru menggunakan tempat belajar yang bervariasi sebagai salah satu upaya meningkatkan minat siswa, karena tinggi rendahnya minat siswa terhadap mata pelajaran tertentu akan berpengaruh terhadap hasil siswa pada mata pelajaran tersebut.

\section{DAFTAR PUSTAKA}

Depdiknas. (2003). Undang-Undang No. 20 tahun 2003 tentang Sistem Pendidikan Nasional. Jakarta: Depdiknas.

Djaali. (2007). Psikologi Pendidikan. Jakarta: Bumi Aksara.

Farida, dkk. (2012). Sekolah yang Menyenangkan: Metode Kreatif Mengajar dan Pengembangan Karakter Siswa. Bandung: Nuansa.

Husamah. (2013). Pembelajaran Luar Kelas Outdoor Learning. Jakarta: Prestasi Pustaka.

Musfiqon. (2015). Panduan Lengkap Metodologi Penelitian Pendidikan. Jakarta: PT. Prestasi Pustakaraya.

Nurdin, Syafruddin. (2005). Guru Profesional \& Implementasi Kurikulum. Jakarta: Quantum Teaching. 
Edutainment : Jurnal Ilmu Pendidikan dan Kependidikan

Volume 8 Nomor 1 Edisi Januari - Juni 2020

Slameto. (2010). Belajar dan Faktor yang Mempengaruhinya. Jakarta: Rineka Cipta. 